\title{
Information Needs of Goat Farmers in Nagpur Division of Maharashtra
}

\author{
Jishant D. Nandeshwar, Sariput P. Landge*, Vaishali V. Banthiya, \\ S.S. Chopade, A.P. Dhok and D.V. Patil \\ Department of Veterinary and Animal Husbandry Extension Education, \\ Nagpur Veterinary College, Nagpur, India \\ *Corresponding author
}

\begin{abstract}
A B S T R A C T
The present study was undertaken to assess the information needs of the goat farmers from Chandrapur and Nagpur districts in Nagpur division of Maharashtra. Selective three blocks were identified and from each talukas 10 goat farmers were selected to make a sample size

\begin{tabular}{|c|}
\hline Keywords \\
\hline $\begin{array}{l}\text { Goat farmers, } \\
\text { Information needs, } \\
\text { Goat, Nagpur, } \\
\text { Maharashtra }\end{array}$ \\
\hline Article Info \\
\hline $\begin{array}{l}\text { Accepted: } \\
26 \text { October } 2018 \\
\text { Available Online: } \\
10 \text { November } 2018\end{array}$ \\
\hline
\end{tabular}
total 60. An ex-post facto research design was used to access the information and data were collected by using structured questionnaire through personal dialogue method. A total of five major areas were assessed viz. feeding management, breeding management, care and management, health care and management and marketing and miscellaneous. Among five major areas $49 \mathrm{sub}$ areas of goat management practices were assessed to know the information needs of the goat farmers. The responses for information needs of the goat farmers were retrieved on three point scale viz. most needed, needed and least needed. The frequency and percentage of each minor area was calculated. Ranking of major and minor areas was done by using total weighted mean score. The results indicated that breeding management (2.57) was perceived as the major areas for information need followed by care and management (2.54), health care management (2.35), marketing and miscellaneous (2.34) and feeding management (2.24). Among sub minor areas feeding of kid, selection of doe, housing of goats, health care and disease control and marketing and miscellaneous areas were perceived as most needed areas for information need in each major areas like feeding management, breeding management, care and management, health care and management and marketing respectively.
\end{abstract}

\section{Introduction}

The term information need is often understood as an individual or group's desire to locate and obtain information to satisfy a conscious or unconscious need (Wikipedia). In India, majority of landholders are marginal farmers having less than 2 acre land wherein agriculture alone is not generating enough for the individual farmers. Hence, most of farmers are moving towards the animal husbandry especially the goat rearing. Subsistence goat farming without proper knowledge is harming the interest of these recourse poor farmers.

Scientific rearing of animal will not only help in improving the management of animal but also will assure guaranteed income for the goat keepers. In this context it is imperative to access the information need of goat farmers so 
that we can provide the necessary information to goat farmers.

\section{Materials and Methods}

The present study was undertaken in purposively selected districts of Chandrapur and Nagpur from Maharashtra state. Three talukas were selected from Chandrapur and Nagpur district and from these talukas 10 goat farmers from each taluka were selected randomly to complete the total sample size of 60 goat farmers. Using an ex- post facto research design the data was collected by using pretested questionnaire through personal dialogue method.

The information needs of the selected goat farmers were assessed in six major areas viz. breeding, feeding, housing, management, health care and marketing \& miscellaneous. Further, major areas were sub divided into various minor areas and information needs of the goat farmers were retrieved by using three point scale viz. most needed, needed and least needed.

The frequency and percentage of each major areas were calculated. Ranking of major and minor areas were done by using total weighted mean score. The results are presented with information in the table and textual presentation.

\section{Results and Discussion}

It is clearly observed from table 1 that breeding management (2.57) was ranked first followed by care and management (2.54), health care management (2.35), marketing and miscellaneous (2.34) while feeding management (2.24) was ranked last for the information needs by the goat keepers. The results are in line with Balaraju et al., (2014) and Jayabhaye (2016). Breeding management was ranked as top most priority areas for information needs by goat farmers and this could be due to the lack of quality animals of specific breeds required for effective weight gain and high prolificacy. Majority of the farmers wants to improve their goat breed and earn more money. Interestingly feeding management was ranked last because present study area were having sufficient grass land, feeds and fodder and it fulfill the nutrient requirement of pastoralist goats.

\section{Information needs on feeding management}

It is evident from the table 2 that feeding of kid (2.67) is ranked first and it might be due to the fact that today's kid are tomorrows adult goat and if the farmers maintain the kid feeding from beginning up to sale it will helps the farmers in terms of higher profits. Feeding of buck (2.60) was ranked second and may goat farmers also referred the breeding buck as half of the herd and also it is required for reproduction in the herd.

Feeding of pregnant goats (2.53) was also adjudged as major areas for information need. This clearly highlighted the importance of pregnant goat and kids to come for improving herd capacity. The last three areas which were reported as less important were urea treatment (1.67) followed by importance of mineral mixture (2.07) and silage making (2.10).

Use of urea treatment was being avoided due to their belief that it may lead to toxicity while the feeding of mineral mixture was not being followed as the goat farmers felt that foraging on variety of grasses available will be sufficient for the growth of the goats while the abundance of feed was quoted as the reason for not following silage making by the goat farmers.

Near similar results were also referred by Senthilikumar and Thanaseelaan (2013) and Tekale et al., (2013). 
Perceived information needs on breeding management areas

Around 65 per cent (Table 1) of the goat farmers perceived breeding management of goats is most important information need. According to table 3 , the top five areas for information requirement are selection of doe (2.92), selection of buck (2.92), flushing procedure (2.82), symptoms of heat (2.68) and pregnancy diagnosis (2.43). Selection of doe and buck in goat farming business is very important as it contribute the fifty per cent of genome in the next generation and better selection has positive impact on the production of kids and gain in body weight. Artificial insemination in goat farming was the least required information domain. It might be due to their understanding that the success rate of artificial insemination is less and the conception rate due to natural mating was good and they were also reluctant in having information about different methods of breeding.
Perceived information needs on care and management of goats

It is evident from the table 4 that majority of the respondents perceived housing for goat (2.90) as the foremost important information needs. Since the study area was surrounded by National parks the fear of wild animals could have been an important reason behind such observation. Care of pregnant animals (2.80) is ranked $2^{\text {nd }}$ because the goat farmer reported that knowledge regarding care of pregnant will directly influence the productivity of the goat farm. Water requirement (2.02) and space requirement (2.43) were the least required information areas as reported by the goat farmers. These findings are in consonance with the report by Sinha et al., (2016).

Since majority of the goat farmers were following semi stall feeding there was no issue for availability of water and space as the region was having the water from Wainganga and Kanhan rivers in the region.

Table.1 Distribution of goat farmers on the basis of perceived information needs on goat management practices

\begin{tabular}{|c|c|c|c|c|c|c|c|}
\hline \multirow{3}{*}{$\begin{array}{l}\text { Sr. } \\
\text { No. }\end{array}$} & \multirow[t]{3}{*}{ Information needs } & \multicolumn{6}{|c|}{$\mathbf{N}=\mathbf{6 0}$} \\
\hline & & $\begin{array}{c}\text { Most } \\
\text { Needed }\end{array}$ & Needed & $\begin{array}{c}\text { Least } \\
\text { Needed }\end{array}$ & $\begin{array}{l}\text { Total } \\
\text { Score }\end{array}$ & TWMS & Rank \\
\hline & & $\%$ & $\%$ & $\%$ & & & \\
\hline 1 & $\begin{array}{l}\text { Feeding } \\
\text { Management }\end{array}$ & 38.47 & 46.95 & 14.58 & 134.34 & 2.24 & V \\
\hline 2 & $\begin{array}{l}\text { Breeding } \\
\text { Management }\end{array}$ & 65.48 & 25.71 & 8.81 & 154 & 2.57 & I \\
\hline 3 & $\begin{array}{l}\text { Care and } \\
\text { Management }\end{array}$ & 62.12 & 29.70 & 8.18 & 152.36 & 2.54 & II \\
\hline 4 & $\begin{array}{l}\text { Health Care } \\
\text { Management }\end{array}$ & 45.95 & 43.10 & 10.95 & 141 & 2.35 & III \\
\hline 5 & Marketing and other & 51.39 & 31.11 & 17.50 & 140.33 & 2.34 & IV \\
\hline
\end{tabular}


Table.2 Distribution of goat farmers on the basis of perceived information needs on feeding management

\begin{tabular}{|c|c|c|c|c|c|c|c|}
\hline \multirow{3}{*}{$\begin{array}{l}\text { Sr. } \\
\text { No. }\end{array}$} & \multirow[t]{3}{*}{ Feeding Areas } & \multicolumn{6}{|r|}{$\mathbf{N}=\mathbf{6 0}$} \\
\hline & & $\begin{array}{c}\text { Most } \\
\text { Needed }\end{array}$ & Needed & Least Needed & $\begin{array}{l}\text { Total } \\
\text { Score }\end{array}$ & TWMS & Rank \\
\hline & & $\%$ & $\%$ & $\%$ & & & \\
\hline 1 & Feeding of does & 45.00 & 35.00 & 20.00 & 135 & 2.25 & V \\
\hline 2 & Feeding of buck & 65.00 & 30.00 & 5.00 & 156 & 2.60 & II \\
\hline 3 & $\begin{array}{l}\text { Feeding of } \\
\text { pregnant goats }\end{array}$ & 58.33 & 36.67 & 5.00 & 152 & 2.53 & III \\
\hline 4 & Feeding of kid & 70.00 & 26.67 & 3.30 & 160 & 2.67 & $\mathrm{I}$ \\
\hline 5 & $\begin{array}{l}\text { Fodder } \\
\text { production }\end{array}$ & 45.00 & 31.67 & 23.33 & 133 & 2.22 & VI \\
\hline 6 & Silage making & 20.00 & 70.00 & 10.00 & 126 & 2.10 & $X$ \\
\hline 7 & Urea treatment & 6.67 & 53.33 & 40.00 & 100 & 1.67 & XII \\
\hline 8 & $\begin{array}{l}\text { Azolla } \\
\text { cultivation }\end{array}$ & 26.67 & 66.67 & 6.67 & 132 & 2.20 & VII \\
\hline 9 & $\begin{array}{l}\text { Hydroponics for } \\
\text { fodder }\end{array}$ & 23.33 & 65.00 & 11.67 & 127 & 2.12 & VIII \\
\hline 10 & $\begin{array}{l}\text { Home-made } \\
\text { concentrates }\end{array}$ & 43.33 & 48.33 & 8.33 & 141 & 2.35 & IV \\
\hline 11 & $\begin{array}{l}\text { Importance of } \\
\text { Mineral mixture }\end{array}$ & 25.00 & 56.67 & 18.33 & 124 & 2.07 & XI \\
\hline 12 & $\begin{array}{l}\text { Use of Chaff } \\
\text { cutter }\end{array}$ & 33.33 & 43.33 & 23.33 & 126 & 2.10 & IX \\
\hline
\end{tabular}

Table.3 Distribution of goat farmers on the basis of perceived information needs on breeding management

\begin{tabular}{|c|c|c|c|c|c|c|c|}
\hline \multirow{3}{*}{$\begin{array}{l}\text { Sr. } \\
\text { No. }\end{array}$} & \multirow[t]{3}{*}{ Breeding Areas } & \multicolumn{6}{|r|}{$\mathbf{N}=60$} \\
\hline & & $\begin{array}{c}\text { Most } \\
\text { Needed }\end{array}$ & Needed & $\begin{array}{c}\text { Least } \\
\text { Needed }\end{array}$ & $\begin{array}{l}\text { Total } \\
\text { Score }\end{array}$ & TWMS & Rank \\
\hline & & $\%$ & $\%$ & $\%$ & & & \\
\hline 1 & Selection of Doe & 93.33 & 5.00 & 1.67 & 175 & 2.92 & I \\
\hline 2 & Selection of Buck & 93.33 & 5.00 & 1.67 & 175 & 2.92 & II \\
\hline 3 & Symptoms of heat & 71.67 & 25.00 & 3.33 & 161 & 2.68 & IV \\
\hline 4 & $\begin{array}{l}\text { Pregnancy } \\
\text { diagnosis }\end{array}$ & 51.67 & 40.00 & 8.33 & 146 & 2.43 & $\mathrm{~V}$ \\
\hline 5 & Flushing procedure & 83.33 & 15.00 & 1.67 & 169 & 2.82 & III \\
\hline 6 & Method of breeding & 35.00 & 46.67 & 18.33 & 130 & 2.17 & VI \\
\hline 7 & $\begin{array}{l}\text { Artificial } \\
\text { Insemination }\end{array}$ & 30.00 & 43.33 & 26.67 & 122 & 2.03 & VII \\
\hline
\end{tabular}


Table.4 Distribution of goat farmers on the basis of perceived information needs on care and management

\begin{tabular}{|c|c|c|c|c|c|c|c|}
\hline \multirow{3}{*}{$\begin{array}{l}\text { Sr. } \\
\text { No. }\end{array}$} & \multirow{3}{*}{$\begin{array}{c}\text { Care and } \\
\text { Management } \\
\text { Area }\end{array}$} & \multicolumn{6}{|r|}{$N=60$} \\
\hline & & $\begin{array}{l}\text { Most } \\
\text { Needed }\end{array}$ & Needed & $\begin{array}{l}\text { Least } \\
\text { Needed }\end{array}$ & $\begin{array}{l}\text { Total } \\
\text { Score }\end{array}$ & TWMS & Rank \\
\hline & & $\%$ & $\%$ & $\%$ & & & \\
\hline 1 & Housing for goats & 90.00 & 10.00 & 0.00 & 174 & 2.90 & I \\
\hline 2 & Space requirement & 46.67 & 50.00 & 3.33 & 146 & 2.43 & VIII \\
\hline $\mathbf{3}$ & Water requirement & 33.33 & 35.00 & 31.67 & 121 & 2.02 & IX \\
\hline 4 & $\begin{array}{l}\text { Care of new born } \\
\text { kid }\end{array}$ & 75.00 & 25.00 & 0.00 & 165 & 2.75 & IV \\
\hline 5 & Care of eves/ buck & 76.67 & 16.67 & 6.67 & 162 & 2.70 & V \\
\hline 6 & $\begin{array}{l}\text { Care of pregnant } \\
\text { animals }\end{array}$ & 80.00 & 20.00 & 0.00 & 168 & 2.80 & II \\
\hline 7 & Castration & 56.67 & 36.67 & 6.67 & 150 & 2.50 & VII \\
\hline 8 & Waste disposal & 76.67 & 16.67 & 6.67 & 162 & 2.70 & VI \\
\hline 9 & Breeds of Goats & 83.33 & 11.67 & 5.00 & 167 & 2.78 & III \\
\hline
\end{tabular}

Table.5 Distribution of goat farmers on the basis of perceived information needs on health care management

\begin{tabular}{|c|c|c|c|c|c|c|c|}
\hline \multirow{3}{*}{$\begin{array}{l}\text { Sr. } \\
\text { No. }\end{array}$} & \multirow{3}{*}{$\begin{array}{l}\text { Health Care } \\
\text { Management }\end{array}$} & \multicolumn{6}{|r|}{$N=60$} \\
\hline & & $\begin{array}{l}\text { Most } \\
\text { Needed }\end{array}$ & Needed & $\begin{array}{l}\text { Least } \\
\text { Needed }\end{array}$ & $\begin{array}{l}\text { Total } \\
\text { Score }\end{array}$ & TWMS & Rank \\
\hline & & $\%$ & $\%$ & $\%$ & & & \\
\hline 1 & $\begin{array}{l}\text { Health care } \\
\text { and disease } \\
\text { control }\end{array}$ & 63.33 & 33.33 & 3.33 & 156 & 2.60 & I \\
\hline 2 & $\begin{array}{l}\text { Vaccination } \\
\text { schedule }\end{array}$ & 51.67 & 46.67 & 1.67 & 150 & 2.50 & IV \\
\hline 3 & $\begin{array}{l}\text { Symptoms of } \\
\text { diseases }\end{array}$ & 31.67 & 51.67 & 16.67 & 129 & 2.15 & VI \\
\hline 4 & $\begin{array}{l}\text { Deworming of } \\
\text { goat }\end{array}$ & 41.67 & 56.67 & 1.67 & 144 & 2.40 & V \\
\hline 5 & $\begin{array}{l}\text { Spraying } \\
\text { insecticides }\end{array}$ & 18.33 & 35.00 & 46.67 & 103 & 1.72 & VII \\
\hline 6 & $\begin{array}{l}\text { Knowledge } \\
\text { about diseases }\end{array}$ & 56.67 & 40.00 & 3.33 & 152 & 2.53 & III \\
\hline 7 & $\begin{array}{l}\text { Exact time of } \\
\text { vaccination }\end{array}$ & 58.33 & 38.33 & 3.33 & 153 & 2.55 & II \\
\hline
\end{tabular}


Table.6 Distribution of goat farmers on the basis of perceived information needs on marketing and other areas

\begin{tabular}{|c|c|c|c|c|c|c|c|}
\hline \multirow{3}{*}{$\begin{array}{l}\text { Sr. } \\
\text { No. }\end{array}$} & \multirow{3}{*}{$\begin{array}{l}\text { Marketing and other } \\
\text { areas }\end{array}$} & \multicolumn{6}{|c|}{$N=60$} \\
\hline & & $\begin{array}{l}\text { Most } \\
\text { Needed }\end{array}$ & Needed & $\begin{array}{l}\text { Least } \\
\text { Needed }\end{array}$ & $\begin{array}{l}\text { Total } \\
\text { Score }\end{array}$ & TWMS & Rank \\
\hline & & $\%$ & $\%$ & $\%$ & & & \\
\hline 1 & $\begin{array}{l}\text { Rearing of goats for milk } \\
\text { production }\end{array}$ & 18.33 & 43.33 & 38.33 & 108 & 1.80 & XI \\
\hline 2 & Rearing goats for meat & 63.33 & 35.00 & 1.67 & 157 & 2.62 & V \\
\hline 3 & $\begin{array}{l}\text { Rearing goats for bakri } \\
\text { eid }\end{array}$ & 80.00 & 16.67 & 3.33 & 166 & 2.77 & III \\
\hline 4 & $\begin{array}{l}\text { Rearing of high quality } \\
\text { breeding buck }\end{array}$ & 83.33 & 16.67 & 0.00 & 170 & 2.83 & I \\
\hline 5 & Government schemes & 73.33 & 20.00 & 6.67 & 160 & 2.67 & IV \\
\hline 6 & Bank loan procedure & 83.33 & 13.33 & 3.33 & 168 & 2.80 & II \\
\hline 7 & Project report & 58.33 & 26.67 & 15.00 & 146 & 2.43 & VII \\
\hline 8 & Insurance for goats & 28.33 & 41.67 & 30.00 & 119 & 1.98 & IX \\
\hline 9 & Method of chevon cuts & 10.00 & 21.67 & 68.33 & 85 & 1.42 & XII \\
\hline 10 & Record Keeping & 53.33 & 40.00 & 6.67 & 148 & 2.47 & VI \\
\hline 11 & Identification of age & 46.67 & 45.00 & 8.33 & 143 & 2.38 & VIII \\
\hline 12 & $\begin{array}{l}\text { Value added product } \\
\text { production }\end{array}$ & 18.33 & 53.33 & 28.33 & 114 & 1.90 & $\mathrm{X}$ \\
\hline
\end{tabular}

Perceived information needs on health care management

The data in the table 5 showed that health care and disease control (2.60) were ranked first. Since the survey was carried out just before the rainy season, goat farmers were more interested in knowing about diseases and its management. Also the fact that annually losses due to diseases and health problem is more that's why majority of them perceived these aspects as most needed information needs. Similar results were reported by Tekale et al., (2013) and Sinha et al., (2016). Exact time of vaccination (2.50) was ranked second because most of the goat farmers were literate and aware about various diseases and to avoid the losses from these diseases timely vaccination is most. The veterinary services providers in study area were providing regular deworming for the goats. Hence, spraying of insecticides (1.73) was adjudged as least required information domain and hence ranked last followed by symptoms from diseases (2.15). In general the veterinary services being provided by the state animal husbandry were well appreciated by the goat owners.

\section{Perceived information needs on marketing and other areas}

According to values in table 6 it is clear that majority of the goat farmers perceived information needs on rearing of high quality breeding buck (2.83) as most important areas of information need followed by bank loan procedure (2.80), rearing goats for bakri eid (2.77), government schemes (2.67), rearing of goat for meat (2.62), project report preparation (2.43), record keeping (2.47) and identification of age (2.38). 
Interestingly, rearing of high quality breeding buck were ranked first because most of them stressed about the importance of buck in improving the weight gain in the next generation. Requirement of initial investment is also an important aspect for the small and marginal farmers to start their goat units and hence, bank loan procedure was perceived as an important information need. Insurance for goats (1.98), value added product production (1.90), rearing of goat for milk production (1.80) and method of chevon cuts (1.42) were the least needed information needs as perceived by goat farmers. Since majority of the goat farmers were not directly involved in the meat sell and marketing the information about meat cuts and value addition was perceived as least important by the goat farmers.

\section{References}

https://en.wikipedia.org/wiki/Information_nee ds (Assessed on 2/10/2018 at time 01:40 $\mathrm{PM})$
Jayabhaye, N. M. (2016) Information needs of Osmanabadi goat entrepreneurs in Marathwada region of Maharashtra state. Unpublished thesis M.V.Sc., Maharashtra Animal and Fishery Sciences University, Nagpur.

Senthilikumar, S. and V. Thanaseelaan (2013) Training needs assessment of small ruminants farmers in southern Tamil Nadu. Indian Journal of Small Ruminants, Vol. 19(2): 232-234.

Sinha, S. K., Mahesh Chander, Braj Mohan and Pachiyappan K. (2016) Information Needs of Goat Rearing Farmers in Mathura District. Ind. J. of Veterinary Sciences and Biotechnology, Vol.11 No. 4: $30-34$.

Tekale, M., D. S. Deshmukh, Prakashkumar Rathod and Manish Sawant (2013) Training Needs of Goat Keepers in Maharashtra. Indian Res. J. Ext. Edu., 13 (2): $67-71$.

\section{How to cite this article:}

Jishant D. Nandeshwar, Sariput P. Landge, Vaishali V. Banthiya, S.S. Chopade, A.P. Dhok and Patil, D.V. 2018. Information Needs of Goat Farmers in Nagpur Division of Maharashtra. Int.J.Curr.Microbiol.App.Sci. 7(11): 3123-3129. doi: https://doi.org/10.20546/ijcmas.2018.711.358 